\title{
Multivariate of forage biomass and nutritive value in pastures of Brachiaria brizantha
}

Raísa Turcato de Oliveira ${ }^{1}$, Rodrigo Amorim Barbosa ${ }^{2}$, Caio Vinicio Vargas de Oliveira ${ }^{1}$, Francielly Paludo ${ }^{1}$, Patrick Bezerra Fernandes ${ }^{3}$

${ }^{1}$ Instituto Federal de Educação, Ciência e Tecnologia Goiano - Campus Rio Verde, GO. ${ }^{2}$ Empresa Brasileira de Pesquisa Agropecuária - Gado de Corte, Campo Grande, MS. ${ }^{3}$ Universidade Federal do Mato Grosso do Sul - UFMS, MS. E-mail: zoo.patrick@hotmail.com

\begin{abstract}
The hypothesis tested was that pastures of the genus Brachiaria, but with variations in forage canopy architecture (canopy height, leaf area index and tiller population density), would not present oscillations in the variables related to primary production and to nutritive value, under similar soil and climate conditions, and under the same management system. Thus, the present work intends to evaluate the different cultivars of Brachiaria brizantha, observing the dissimilarity of the variables related to forage biomass and nutritive value. The experiment was conducted by Embrapa beef cattle. The design was completely randomized blocks with three replicates. The treatments were three ecotypes of Brachiaria brizantha, B4, BRS Paiaguás and Xaraés. The grazing method used was the intermittent variable stocking rate. The data of forage canopy height (FCH), tiller population density (TPD) and leaf area index (LAI) were submitted to analysis of variance. Estimates of the first and second canonical variables, as well as standardized canonical coefficients were performed. It was noticed oscillations at the $\mathrm{FCH}$ between the grasses, in which, pastures of ecotype B4 present the highest height in relation to the other B. brizantha. BRS Paiaguás presents the highest TPD. The standard canonical coefficients of the first canonical variable showed that neutral detergent fiber (NDF) and lignin are the variables that most affect the first canonical variable, positively and negatively. This indicates that these are the variables that most interfere in the differentiation of characteristics related to the nutritive value of $B$. brizantha grasses. The first canonical variable explains $80.5 \%$ of the $B$. brizantha pasture variation, in addition, it is possible to observe a differentiated distribution among the pastures studied. The $B$. brizantha pastures present variations in forage canopy architecture, which end up impacted by the canopy lignin concentration.
\end{abstract}

Key words: grow crops; lignin; dissimilarity.

\section{Multivariada da biomassa de forragem e valor nutritivo em pastos de Brachiaria brizantha}

\section{Resumo}

A hipótese testada foi que pastagens do gênero Brachiaria, mas com variações na arquitetura do dossel forrageiro (altura do dossel, índice de área foliar e densidade populacional dos perfilhos), não apresentariam oscilações nas variáveis relacionadas à produção primária e valor nutritivo, em condições edofoclimáticas semelhantes, e sob o mesmo sistema de manejo. Assim, o presente trabalho pretende avaliar as diferentes cultivares de Brachiaria brizantha, observando a dissimilaridade das variáveis relacionadas à biomassa e valor nutritivo. $\mathrm{O}$ experimento foi conduzido na Embrapa Gado de Corte. $\mathrm{O}$ delineamento foi de blocos casualizados, com três repetições. Os tratamentos foram três ecótipos de Brachiaria brizantha, B4, BRS Paiaguás e Xaraés. O método de pastejo utilizado foi o de lotação intermitente com taxa de lotação variada. Os dados de altura do dossel forrageiro (ADF), densidade populacional dos perfilhos (DPP) e índice de área foliar (IAF) foram submetidos à análise de variância. As estimativas da primeira e segunda variáveis canônicas, bem como os coeficientes canônicos padronizados foram realizadas. Observou-se oscilações no ADF entre as gramíneas, em que, pastos do ecótipo B4 apresentam a maior altura em relação aos demais $B$. brizantha. A BRS Paiaguás apresenta o maior DPP. Os coeficientes canônicos padrões da primeira variável canônica mostraram que a fibra em detergente neutro (FDN) e a lignina são as variáveis que mais afetam a primeira variável canônica, positiva e negativamente. 
Isso indica que essas são as variáveis que mais interferem na diferenciação de características relacionadas ao valor nutritivo de gramíneas de $B$. brizantha. A primeira variável canônica explica $80,5 \%$ da variação da pastagem de $B$. brizantha, além disso, é possível observar uma distribuição diferenciada entre as pastagens estudadas. As pastagens de $B$. brizantha apresentam variações na arquitetura da copa forrageira, que acabam impactadas pela concentração de lignina do dossel.

Palavras-chave: cultivar; lignina; dissimilaridade.

\section{Introduction}

One of the livestock needs is to maintain satisfactory levels of forage production, achieving sustainable animal production over the years. For this, not only the management of the pastures is necessary, but an even more impressive solution would be the choice of cultivars with better performance, adapted to the different ecosystems of Brazil and also the diverse situations that the producer has (REIS et al., 2014).

Some studies only report for a very short period, which does not exceed a growing season or using animals that are only defoliation agents, disregarding the various processes that occur in the pasture ecosystem, which changes constantly according to the season, the level of precipitation, soil type, animal category, amount of sunlight, forage used. These characteristics make this system dynamic and if not considered, make the search general and irrelevant to the real system that occurs in the practice of the producer (SILVA; NASCIMENTO JUNIOR, 2006).

Therefore, the hypothesis tested was that pastures of the genus Brachiaria, but with variations in forage canopy architecture (canopy height, leaf area index and tillers population density), would not present oscillations in the variables related to primary production and to nutritive value, under similar soil and climate conditions, and under the same management system.

Thus, the present work intends to evaluate the different cultivars of Brachiaria brizantha, observing the dissimilarity of the variables related to forage biomass and nutritive value.

\section{Material and Methods}

The experiment was conducted by the Embrapa beef cattle, located in Campo Grande MS, Lat. 2027 'S, Long 5437' W and Alt. 530m), and beginning of assessments in september 2015, finalizing in April 2016. The climate of the region, according to the classification of Köppen, is tropical rainy type savannah, subtype Aw, characterized by the well defined occurrence of the dry period during the colder months of the year, and rainy season during the summer months (Figure 1).

Figure 1. Average, minimum and maximum temperatures, monthly precipitation from september 2015 to april 2016. 


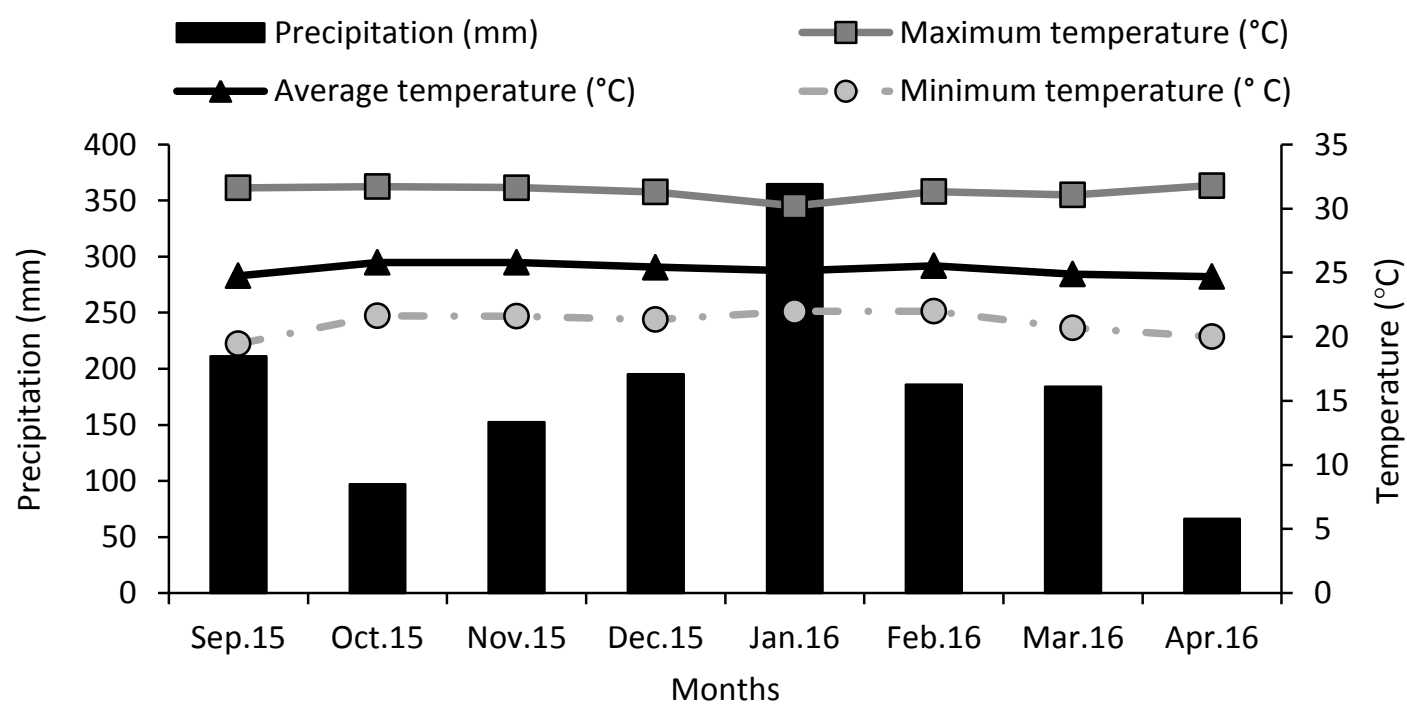

The experiment occupied an area of 13.5 hectares (ha). In addition, the experiment also had a reserve area of 7.0 ha with Panicum maximun $\mathrm{cV}$. Massai, for the regulating animals. The design was completely randomized blocks with three replicates. The treatments were three ecotypes of Brachiaria brizantha, B4, BRS Paiaguás and Xaraés. Each treatment was allocated in plots of 1.5 ha which were later subdivided into six picks of 0.25 ha.

For the experiment, soil samples $(0-20$ $\mathrm{cm}$ ) were collected for fertility analysis. The soil of the experimental area is classified as Red Latosol Dystrophic, characterized by clay texture, acid $\mathrm{pH}$, low base saturation and high aluminum concentration. Thus, from 2010 the conventional soil preparation, with correction with dolomitic limestone was done, with the objective of increasing the saturation by bases to $50 \% .40 \mathrm{~kg}$ ha ${ }^{-1}$ of $\mathrm{P}_{2} \mathrm{O}_{5}$ and $\mathrm{K}_{2} \mathrm{O}$ were used, raising the phosphorus content to 4-8 $\mathrm{mg} \mathrm{dm}^{-3}$ (P-Mehlich1) and the potassium content to $60-80 \mathrm{mg} \mathrm{dm}^{-3}$ and $50 \mathrm{~kg} \mathrm{ha}^{-1}$ from FTE-BR12. $150 \mathrm{~kg} \mathrm{ha}^{-1}$ of $\mathrm{N}$ in the form of urea were also applied, divided into three plots in the months of november, december and february of each year.

The grazing method used was the intermittent variable stocking rate. The grazing intervals corresponded to 25 days of rest and 5 days of grazing in the rainy season, and 35 days of rest and 7 days of grazing in the dry season. Eighty Bos taurus $x$ Bos indicus steers were used, with approximately 7 months of age and initial average weight of $180 \mathrm{~kg}$. Of these, four animals were used as testers - animals that are considered for performance evaluation - being thus, 36 animals, and 44 control animals - animals that are used to control the height, avoiding super and sub grazing. Animals was in the area from september 2015 to april 2016. The tester's animals were weighed every 28 days, thus, the daily average gain was estimated. The stocking rate (animal unit $[\mathrm{AU}]$ equivalent to $450 \mathrm{~kg}$ ) used for the water season was $5 \mathrm{AU} \mathrm{ha}^{-1} \mathrm{~B} 4,4 \mathrm{AU}_{\mathrm{ha}}{ }^{-1}$ BRS Paiaguás and $5 \mathrm{AU}$ ha $^{-1}$ Xaraés; in the dry period was $1 \mathrm{AU}$ ha ${ }^{-1} \mathrm{~B} 4,2 \mathrm{AU}$ ha ${ }^{-1}$ BRS Paiaguás and $2 \mathrm{AU}$ ha ${ }^{-1}$ Xaraés.

The animals were treated with acaricide for controlling ticks every 28 days, following the protocol of the drug used; and in this occasion they were weighed and the adjustment of the stocking rate was carried out. Mineral salt was also fed to the animals throughout the experiment, with the amount followed by the recommendation of the product.

For the estimation of pre-grazing height, 30 random points were recorded in a sub-plot of each module. This information corresponded to the average heights, in centimeters, around the ruler.

A total of 300 green leaf blades were collected, 100 of each grass being used for the integration of leaf area for leaf area estimation $\left(\right.$ LA $\mathrm{cm}^{2}$ ). Tiller population density (TPD) was estimated with the aid of three $1 \mathrm{~m}^{2}$ frames, randomly allocated within each sub-plot, always at the time of pre-grazing of each cycle. The number of tillers contained within each frame was recorded, which later integrated the mean for each treatment. Thus, it was possible to obtain the leaf area index (LAI) estimates given by the following formula: LAI= (LA $\times$ TPD) / soil area (adapted from GASTAL; LEMAIRE, 2015). 
For the quantification of the forage mass, nine samples were collected by pickets every 25 days in the water period and 35 days in the dry season. Whole plant fodder collection was done using a metal frame with $1 \mathrm{~m}^{2}$ at nine points within each picket, each of the nine samples were placed in plastic bags and identified with labels containing information of which picket, subpitch, sample number and date of collection.

After forage harvesting of the whole plant, the samples were taken to the laboratory and weighed. Then they were placed in paper bags and taken to a forced circulation oven at 55 ${ }^{\circ} \mathrm{C}$ for 72 hours. After this period the samples were again weighed to determine forage biomass. The samples were then ground to a Willey type mill with a $1 \mathrm{~mm}$ sieve, conditioned in plastic bags containing identification coding and taken to the Embrapa's Animal Nutrition Laboratory, for the performance of the bromatological analyzes. In the laboratory, the milled samples were placed in the cuvettes filling their entire bottom, with about 1 to 2 grams of each sample. The crude protein (CP), neutral detergent fiber (NDF), acid detergent fiber (ADF) in vitro organic matter digestibility (IVOMD), lignin, cellulose and silica. Also, about $20 \%$ of the samples had their estimated nutritional value wet, if there was a need for near infrared spectroscopy analysis calibration (SILVA; QUEIROZ, 2002).

The forage canopy height (FCH), TPD and LAl data were submitted to analysis of variance: in the model the main factors were taken into account: grass, season of the year (plot subdivided in time) and grass and season $x$ interaction of the year. When appropriate, the multiple comparison Tukey's test was performed at a $5 \%$ significance level.

Estimates of the first and second canonical variables, as well as standardized canonical coefficients were performed. The Candisc function of R 3.5.0 software was used for this estimation.

\section{Results and Discussion}

For the variables related to the characterization of the forage canopy, no interaction effect between grasses and seasons of the year ( $p>0.05)$ was observed. On the other hand, there were oscillations at the $\mathrm{FCH}$ between the grasses, in which pastures of ecotype B4 present the highest height in relation to the other B. brizantha. BRS Paiaguás presents the highest TPD. Regarding the LAI, it is possible to infer that proportionality occurs between the grasses. However, there was a reduction of $23 \%$ of the LAI in the dry season (Table 1).

Table 1. Characterization of the forage canopy architecture of Brachiaria brizantha pastures at the seasons.

\begin{tabular}{|c|c|c|c|c|c|c|c|c|c|}
\hline \multirow[b]{2}{*}{ Variable } & \multicolumn{3}{|c|}{ Grass } & \multicolumn{2}{|c|}{ Season } & \multirow[b]{2}{*}{ SE } & \multicolumn{3}{|c|}{$p$-value } \\
\hline & Ecotype B4 & BRS Paiaguás & Xaraés & Waters & Dry & & Grass & Season & Interaction \\
\hline $\mathrm{FCH}(\mathrm{cm})$ & $34^{\mathrm{a}}$ & $26^{\mathrm{ab}}$ & $21^{\mathrm{b}}$ & $30^{\mathrm{a}}$ & $20^{b}$ & 2.22 & 0.022 & 0.031 & 0.519 \\
\hline $\operatorname{TPD}\left(\mathrm{m}^{2}\right)$ & $215^{b}$ & $421^{a}$ & $277^{b}$ & $325^{\mathrm{a}}$ & $263^{b}$ & 20.26 & 0.002 & 0.017 & 0.560 \\
\hline LAI & 2.66 & 2.43 & 2.62 & $2.78^{\mathrm{a}}$ & $2.14^{\mathrm{b}}$ & 0.122 & 0.543 & 0.015 & 0.667 \\
\hline
\end{tabular}

FCH: forage canopy height; TPD: tiller population density; LAl: leaf area index: averages followed by lower case letters in the lines differ from each other by Tukey's test, at $5 \%$ probability. SE: standard error of the mean. $p$-value: significant effect probability.

The LAI and TPD are closely related (GASTAL; LEMAIRE, 2015), so the reduction of the tillering rate reduces leaf area dynamics (BARBOSA et al., 2011; MONTAGNER et al., 2011) as observed in Table 1. In addition, it is possible to predict that this behavior is applied to the three Brachiaria brizantha, suggesting that as a mechanism of adaptation to the management, these grasses present the same LAI.

The standard canonical coefficients of the first canonical variable (Can1), showed that NDF and lignin are the variables that most affect the first canonical variable, positively and negatively. This indicates that these are the variables that most interfere in the differentiation of 
characteristics related to the nutritive value of $B$.

brizantha grasses (Table 2).

Table 2. Standardized canonical coefficients of the first (Can1) and second canonical variable (Can2) of Brachiaria brizantha pastures.

\begin{tabular}{ccc}
\hline Variable & Can1 & Can2 \\
\hline FM & 0.181 & -1.35 \\
ADG & 0.607 & -0.25 \\
CP & 0.007 & -0.87 \\
NDF & 1.68 & 1.02 \\
ADF & 0.197 & -3.23 \\
IVOMD & 0.127 & 2.31 \\
Lignin & -1.91 & 1.60 \\
Cellulose & 1.19 & 2.73 \\
Silica & -0.489 & 2.23 \\
\hline
\end{tabular}

FM: forage mass; ADG: average daily gain; CP: crude protein; NDF: neutral detergent fiber: ADF: acid detergent fiber; IVOMD: in vitro organic matter digestibility.

Lignin plays a significant role in tropical climate grasses, as the plant progresses to the pre-inflorescence and flowering phases, resulting in a higher deposition of this polymer in the cell wall (AGNUSDEl et al., 2011; TAIZ; ZEIGER, 2009). On the other hand, in grazing environments, the grazing pattern performed by the animals reduces the density of reproductive tillers (HODGSON, 1990). In this study, it is possible to evaluate the nutrient value of the forage canopy in the studied pastures (BENVENUTTI et al., 2009; ROMERA et al., 2012).

The first canonical variable (Can1) explains $80.5 \%$ of the $B$. brizantha pasture variation, in addition, it is possible to observe a differentiated distribution among the pastures studied (Figure 2). evaluate the effect of the forage stock on the nutrient value of the forage canopy, and to

Figure 2. Distribution of the first (x-axis) and second (y-axis) canonical variable of the pastures Brachiaria brizantha (ecotype B4 [¥], BRS Paiaguás [§] and Xaraés [+]).

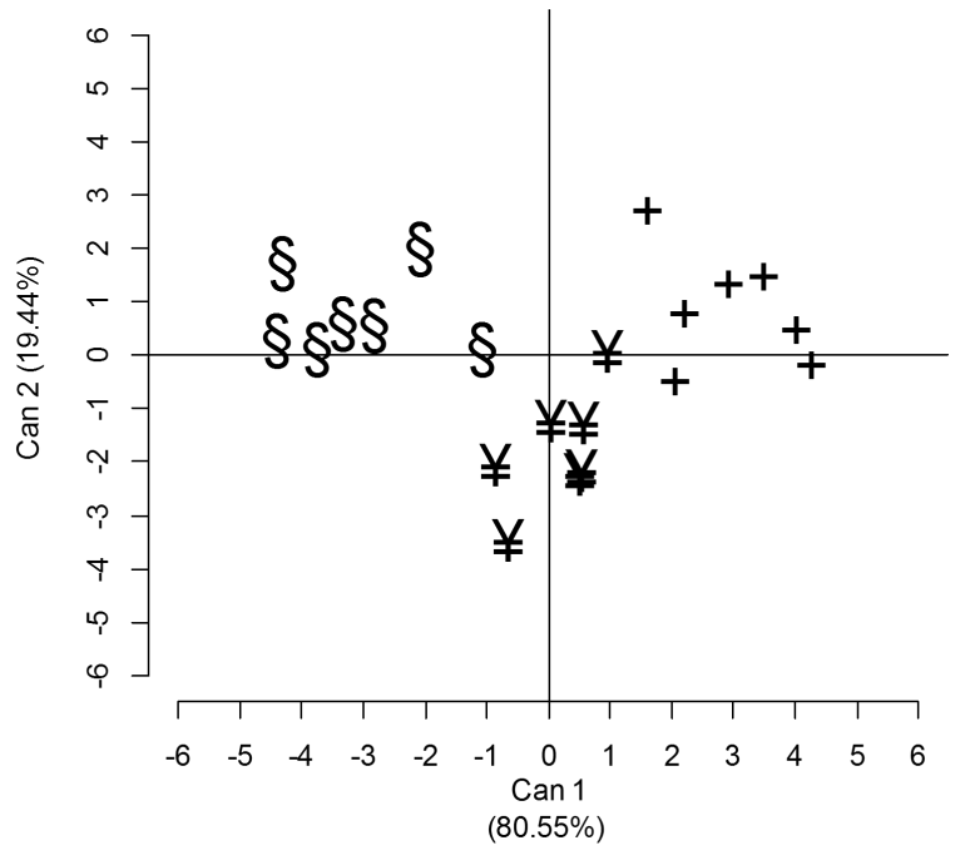

The pastures of ecotype B4 present predominant points distributed in Can1 negative, while BRS Paiaguás present points in Can1 positive, cv. Xaraés presents predominant equidistributed points in positive and negative Can1. Thus, it is possible to infer that the ecotype 
B4 stands out for high values of lignin, BRS Paiaguás presents a greater association with NDF and for Xaraés it is possible to observe a balance between NDF and lignin.

The ecotype B4 presents the less dense forage canopy as well as the Xaraés (Table 1), but due to its greater association with lignin, it suggests that the highest canopy height was composed of a stem, thus, this pasture presents the least nutritive value. On the other hand, none of the grasses had any association with ADG.

This suggests that the type of management adopted (fixed days) allows to flexibilize the animal production to grass. On the other hand, the association of the ecotype B4 with lignin infers that the animals during grazing had to spend more energy with the defoliation, since, when the lignin concentration increases, there is an increase in the number of bites and a reduction in the depth of defoliation, which can reduce the use of the foraging resource produced (BENVENUTTI et al., 2009; FONSECA et al., 2012).

Therefore, in spite of the possible similarity in ADG among $B$. brizantha pastures, it is recommended to use as foraging resources the cultivar Xaraés and BRS Paiaguás, due to the positive associations with the responsible variables that control forage consumption (BENVENUTTI et al., 2015).

\section{Conclusion}

The $B$. brizantha pastures present variations in forage canopy architecture, which end up impacted by the canopy lignin concentration.

\section{Acknowledgements}

We thank the Goiano Federal Institute Campus Rio Verde and Embrapa beef cattle for the support of this study, and FAPEG for granting the scholarship.

\section{References}

AGNUSDEI, M.G.; MARCO, O.N.; NENNING, F. R.; AELLO, M.S. Leaf blade nutritional quality of rhodes grass (Chloris gayana) as affected by leaf age and length. Crop and Pasture Science, v.62, n.12, p.1098-1105, 2011. https://doi.org/10.1071/CP11164

BARBOSA, R.A.; NASCIMENTO JÚNIOR, D.D.; VILELA, H.H., SILVA, S.C.D.; EUCLIDES, V.P.B.; SBRISSIA, A.F.; SOUSA, B.M.D.L. Morphogenic and structural characteristics of guinea grass pastures submitted to three frequencies and two defoliation severities. Revista Brasileira de Zootecnia, v.40, n.5, p.947-954, 2011. https://doi.org/10.1590/S1516$\underline{35982011000500002}$

BENVENUTTI, M.A.; GORDON, I.J.; POPPI, D.P.; CROWTHER, R.; SPINKS, W.; MORENO, F.C. The horizontal barrier effect of stems on the foraging behaviour of cattle grazing five tropical grasses. Livestock Science, v.126, n.1, p.229-238, 2009. ttps://doi.org/10.1016/j.livsci.2009.07.006

BENVENUTTI, M.A.; PAVETTI, D.R.; POPPI, D.P.; GORDON, I.J.; CANGIANO, C.A. Defoliation patterns and their implications for the management of vegetative tropical pastures to control intake and diet quality by cattle. Grass and Forage Science, v.71, n.3, p.424-436, 2015. https://doi.org/10.1111/gfs.12186

FONSECA, L.; MEZZALIRA, J.C.; BREMM, C.; CARVALHO, P.C.F. Grazing by horizon: what would be the limits to maintain maximum shortterm herbage intake rate? Grassland Science in Europe, v.17, p.237-239, 2012.

GASTAL, F.; LEMAIRE, G. Defoliation, shoot plasticity, sward structure and herbage utilization in pasture: Review of the underlying ecophysiological processes. Agriculture, v.5, n.4, p.1146-1171, 2015. https://doi.org/10.3390/agriculture5041146

REIS, R.A.; BERNARDES, T.F.; SIQUEIRA, G.R. Forragicultura: ciência, tecnologia e gestão dos recursos forrageiros. Jaboticabal: Gráfica Multipress, 2014.

ROMERA, A.J.; BURGES, J.C.; GREGORINI, P.; AGNUSDEI, M.G. Morphological components of Thynopirum ponticum tillers and their contribution to the diet of cattle grazing at contrasting herbage allowances. Livestock Science, v.150, n.1, p.284-292, 2012. https://doi.org/10.1016/i.livsci.2012.09.013

SILVA, D.J.; QUEIROZ, A.C. Análise de alimentos: métodos químicos e biológicos. 3. ed. Viçosa: UFV, 2002. 235p.

SILVA, S.C; NASCIMENTO JUNIOR, D. Ecofisiologia de plantas forrageiras. In: PEREIRA, O.G.; OBEID, J.A.; NASCIMENTO JUNIOR., D.; FONSECA, D.M., 
eds. In: SIMPÓSIO SOBRE MANEJO ESTRATÉGICO

DA PASTAGEM, 3. Viçosa, 2006. Anais [...]. Viçosa: UFV, 2006. p.1-42.

TAIZ, L.; ZEIGER, E. Fisiologia vegetal. 4. ed. Porto Alegre: Artmed, 2009. 848p. 